The Principles of Electric Power Transmission by Alternating Currents

By H. Waddicor. Fourth edition, revised. .Pp. xxi+458. (London: Chapman and Hall, Ltd., 1939.) $21 s$. net.

7 HAT this well-known and valued text-book, first published in 1928, has appeared in its fourth edition is a remarkable achievement and bears testimony to the author's ability. The principal alterations introduced in the present edition refer to underground cables, and recent extensive research and development work in connexion with the thermal properties of eables is set out in the revised Chapter $\mathbf{x}$. There is an excellent bibliography with up-to-date references. For some obscure reason the index is not so complete as could be wished; for example, the name of J. A. Fleming appears in the text but not in the index.

When dealing with the theory of electrically long lines, the author evidently prefers the term "line angle" for the complex quantity $\sqrt{Z Y}$, rather than the "propagation constant" commonly used in telecommunication practice and by other writers on power transmission. Students at universities and technical colleges, to whom the author refers in the preface to his book, are likely to desire a wider and more generalized outlook on transmission problems and theory. In view of this, it is hoped that, in a future edition, at least mention may be made of attenuation, wave velocity and the conditions underlying reflection in long lines. Recent developments in the protection of high-voltage transformer windings (non-resonating) are mentioned but no details given.

The book is well illustrated and beautifully printed, and in the reviewer's experience is known to suit the requirements of students of power engineering, and for such the book is recommended without reserve.

Gmelins Handbuch der anorganischen Chemie

Achte völlig neu bearbeitete Auflage. Herausgegeben von der Deutschen Chemischen Gesellschaft. SystemNummer 35 : Aluminium. Teil A, Lief. 6 : Legierung von Aluminium mit Mangan bis Rhenium. Pp. 887-1110+xxii. (Berlin: Verlag Chemie, G.m.b.H., 1939.) 27.75 gold marks.

$\triangle$ COMPREHENSIVE account of the composition, A chemical and physical properties of the alloys of aluminium with manganese, nickel, cobalt, silver, gold, platinum and various other metals is included in the part of "Gmelins Handbuch" under notice. The views of various authorities on the composition of the solid phases in the system Al-Mn are contradictory and are set forth in a series of diagrams for comparison. Four intermetallic compounds, $\mathrm{Al}_{6} \mathrm{Mn}$, $\mathrm{Al}_{4} \mathrm{Mn}, \mathrm{Al}_{3} \mathrm{Mn}$ and $\mathrm{AlMn}$, have been identified, of which only the last-mentioned has a congruent melting point at $1287^{\circ} \mathrm{C}$. These alloys are not affected by dry air, but disintegrate when the air is moist. Aluminium mixes with nickel in all proportions in the liquid state and a compound, AlNi, separates at $1640^{\circ} \mathrm{C}$. The slow disintegration of these alloys in moist air is accelerated by the presence of other intermetallic compounds.

Much space is given to the alloys with silver, although there is still some uncertainty about the composition of the solid phases in alloys containing more than 14 per cent of aluminium. Whereas the solubility of aluminium in silver varies between $5 \cdot 1$ per cent at $200^{\circ} \mathrm{C}$. and 6.52 per cent at $500^{\circ} \mathrm{C}$., that of silver in aluminium increases from 0.75 per cent to about 48 per cent in the same temperature range. The intermetallic compound $\mathrm{Ag}_{3} \mathrm{Al}$ melts at $779^{\circ} \mathrm{C}$. Several ternary and quaternary alloys are also discussed in this number, which is packed with detail and well illustrated with diagrams.

\section{Direct and Alternating Currents}

Theory and Machinery. By E. A. Loew. Second edition. Pp. $\mathrm{xv}+730$. (New York and London : McGraw-Hill Book Co., Inc., 1938.) 25s.

$7 \mathrm{HE}$ second edition of this text-book is a creditable effort on the part of the author to cover, in a single volume of 730 pages, the extensive field embracing the theory and applications of direct and alternating current circuits, machinery and apparatus. Numerous examples are given to illustrate the principles of direct current and alternating current machinery and in addition there is a selection of problems, at the end of most chapters, which are suitable for tutorial classes. The treatment of the subject is of an introductory nature, but, although not sufficiently advanced to suit the requirements of a degree course syllabus in a British university, this book would assist students attending a course of lectures on a general survey of the subject of D.c. and A.c. machinery and apparatus. Throughout the book there is evidence of the restriction, imposed by lack of space, on the treatment of the problems involved and this offsets much of the gain in having the whole subject in a single volume.

The final chapter, on thermionic apparatus, while commendable as a brief and interesting survey, would have been much enhanced in value had the author included worked examples and a selection of problems.

\section{Direct-Current Machinery}

By Prof. Hempstead S. Bull. Pp. vi+318. (New York: John Wiley and Sons, Inc.; London: Chapman and Hall, Ltd., 1939.) 15s. net.

A STUDENT having limited time for the study A of the principles of direct current machinery will find this book useful as a general survey of the subject. The treatment is elementary but, so far as it goes, is satisfactory and well presented in the 318 pages and adequate illustrations.

As there is little matter not to be found in existing text-books this is a disappointing feature and renders the book of little use to the advanced student or designer. Each chapter is provided with a useful bibliography, mainly American, and a set of problems.

The importance of the direct current motor has resulted in notable advances in the available information about heating and improvements in the design and construction of modern machines. The book contains little information about temperature rise and the disposal of heat generated in the active materials, and therefore cannot be regarded as an up-to-date treatise. 